\title{
Perubahan kadar hemoglobin akibat terapi kurkuminoid ekstrak rimpang kunyit dibandingkan natrium diklofenak pada penderita osteoartritis
}

\author{
Nyoman Kertia1, Ahmad Husain Asdie², Wasilah Rochmah³, Marsetyawan ${ }^{4}$
}

\begin{abstract}
Background: In general, patients with osteoarthritis require long live treatments, especially anti-inflammatory drugs. Non steroidal anti inflammatory drugs are mostly follow by some side effects such as dyspepsia and gastrointestinal bleeding. The use of natural medicine for rheumatic diseases have commonly been practiced worldwide.

Objectives: To learn the changes of hemoglobin level due to treatment with curcuminoid from Curcuma domestica Val. rhizome extract compared to diclofenac sodium as anti-inflammatory agent for the treatment of osteoarthritis.

Methods: This research is a prospective randomized open end blinded evaluations (PROBE). Patients treated with 30 mg curcuminoid from Curcuma domestica Val. rhizome extract or $25 \mathrm{mg}$ diclofenac sodium three times daily for 4 weeks respectively. The hemoglobin level was checked before and after treatment.

Results: A total of 80 patients with knee osteoarthritis participated in this study. There was no significant difference in the frequency of sex, educational level, duration of suffering, percentage of co-morbidities in both groups. There was no significant different of hemoglobin level before treatment between both treatment group. The hemoglobin level was increase significantly in curcuminoid treatment groups while no significant change in diclofenac group. Treatment with curcuminoid increasing the hemoglobin level significantly compare to diclofenac sodium $(p=0.03)$.

Conclusion: Treatment with curcuminoid from Curcuma domestica Val. rhizome increasing the hemoglobin level significantly compare to diclofenac sodium treatment for osteoarthritis.
\end{abstract}

KEY WORDS change of hemoglobin concentration, curcuminoid, diclofenac sodium, osteoarthritis

\section{PENDAHULUAN}

Obat anti-inflamasi adalah obat yang mempunyai aktivitas menekan proses inflamasi, digunakan untuk menekan peradangan pada jaringan tubuh. Obat antiinflamasi dibedakan menjadi dua golongan, yaitu golongan steroid dan golongan non-steroid. Berhubung banyaknya efek samping obat anti-inflamasi golongan steroid, maka saat ini obat anti-inflamasi yang banyak digunakan adalah obat anti-inflamasi nonsteroid (OAINS). Bukti-bukti penelitian menunjukkan bahwa OAINS mempunyai efek samping yang serius terutama jika dipergunakan dalam jangka lama, lebih-lebih pada pasien usia lanjut. Efek samping OAINS dapat berupa perdarahan saluran cerna, gangguan fungsi hati, ginjal, sumsum tulang, serangan jantung, dan stroke (1).

Natrium diklofenak adalah salah satu OAINS yang tergolong preferentially COX inhibitor yang banyak diresepkan. Pengertian preferentially COX inhibitor adalah OAINS yang termasuk dalam golongan ini menghambat aktivitas enzim COX-1 dan COX-2 dalam porsi yang seimbang, sehingga secara umum lebih aman terhadap saluran cerna dan ginjal jika dibandingkan dengan OAINS yang selektif menghambat COX-1 serta lebih aman terhadap sistem kardiovaskuler jika dibandingkan dengan OAINS yang selektif menghambat COX-2 (2). Obat antiinflamasi non-steroid (OAINS) tidak hanya menghambat aktivitas enzim COX-2, tetapi juga menghambat sintesis enzim COX-2 oleh makrofag cairan sinovia sendi yang terserang osteoartritis (OA) (3).

Penggunaan obat bahan alam untuk mengobati penyakit sudah ribuan tahun diterapkan oleh masyarakat luas, baik di Indonesia maupun di negara lain. Data penelitian di Kotamadya dan Kabupaten Malang pada tahun 1994 menunjukkan bahwa penduduk yang menggunakan jamu untuk pengobatan penyakit reumatik masing-masing adalah 476 orang dan 580 orang per seribu pasien (4). Sekitar $70 \%$ dari jamu di Indonesia menggunakan bahan dasar yang diekstrak dari rimpang kurkuma seperti kunyit dan temulawak (5). ${ }^{1234}$

Kurkumin mempunyai aktivitas anti-inflamasi (6), mencegah dan mengobati ulkus lambung $(7,8)$, antihepatotoksis, dan kolagogum $(9,10)$ serta anti tumor $(6,11)$. Keuntungan lain dari kombinasi kurkuminoid ekstrak rimpang kunyit dan minyak atsiri ekstrak rimpang temulawak adalah lebih murah, lebih efektif dalam memperbaiki

$1{ }^{1}$ Divisi Rematologi, Bagian Penyakit Dalam Fakultas Kedoktreran UGM/ RSUP Dr. Sardjito, Daerah Istimewa Yogyakarta, e-mail: nyomankertia@ yahoo.com

$2^{2}$ Divisi Endokrinologi, Metabolisme, dan Diabetes, Bagian Penyakit Dalam Fakultas Kedoktreran UGM/RSUP Dr. Sardjito, Daerah Istimewa Yogyakarta

$3^{3}$ Divisi Geriatri, Bagian Penyakit Dalam Fakultas Kedoktreran UGM/ RSUP Dr. Sardjito, Daerah Istimewa Yogyakarta

$4{ }^{4}$ Bagian Histologi dan Biologi Sel, Fakultas Kedokteran UGM, Daerah Istimewa Yogyakarta 
keadaan fisik, cenderung memperbaiki fungsi hati, ginjal, dan saluran cerna, sedangkan piroksikam memperburuk fungsinya (12).

Penelitian pendahuluan pernah dilakukan pada tahun 2004 dengan melibatkan 20 pasien yang menderita OA lutut. Hasilnya adalah pemberian 3 x 30 mg kurkuminoid ekstrak rimpang kunyit secara bermakna menurunkan angka leukosit dan kadar MDA cairan sinovia serta mengurangi rasa nyeri sendi, namun kemampuannya tidak berbeda bermakna dibandingkan dengan terapi 3 x 25 mg natrium diklofenak. Dispepsia yang terjadi lebih ringan pada kelompok terapi kurkuminoid_dibandingkan natrium diklofenak (13). Rendahnya kadar hemoglobin atau anemia akan menurunkan fungsi kognitif, meningkatkan morbiditas, dan mortalitas pada populasi lanjut usia (14). Seperti diketahui bahwa osteoartritis adalah penyakit degeneratif yang terbanyak menyerang populasi lanjut usia, maka menarik untuk diteliti apakah kejadian dispepsia ini berpengaruh terhadap perubahan kadar hemoglobin pada penderita osteoartritis? Tujuan penelitian adalah untuk mengetahui perubahan kadar hemoglobin akibat terapi kurkuminoid ekstrak rimpang kunyit dibandingkan dengan natrium diklofenak pada penderita osteoartritis.

\section{BAHAN DAN METODE}

Penelitian ini dirancang sebagai studi analisis eksperimental menggunakan metode penelitian prospective randomized open end blinded evaluations (PROBE). Bahan penelitian antara lain bahan untuk formulasi kapsul kurkuminoid ekstrak rimpang kunyit yang terdiri dari: kurkuminoid ekstrak rimpang kunyit, cangkang kapsul, bahan pengisi, dan bahan untuk formulasi kapsul natrium diklofenak yang terdiri dari: serbuk natrium diklofenak, cangkang kapsul, bahan pengisi. Perbandingan kadar relatif komponen kurkuminoid yang terkandung di dalam kapsul bahan uji adalah 52,93\% kurkumin, 21,63\% desmetoksi kurkumin, dan 25,43\% bisdesmetoksi kurkumin. Subjek dibagi menjadi 2 kelompok, yaitu kelompok yang mendapat terapi kurkuminoid ekstrak rimpang kunyit (kelompok perlakuan) dan kelompok yang mendapat terapi natrium diklofenak (kelompok kontrol).

Populasi penelitian adalah pasien dengan OA lutut yang terdaftar dan masih bisa ditemui di Rumah Sakit Umum Pusat Dr. Sardjito Yogyakarta. Subjek penelitian adalah penderita OA lutut berumur lebih dari 50 tahun, tidak mempunyai penyakit artritis selain osteoartritis, tidak mempunyai kelainan fungsi hati, ginjal atau sumsum tulang, tidak mempunyai riwayat penyakit gastritis, ulkus peptikum atau ulkus duodenum, tidak hipersensitif terhadap kurkuma atau natrium diklofenak, tidak menggunakan obat anti koagulan atau obat antiinflamasi lain, dan setuju mengikuti penelitian dengan menandatangani informed consent. Penghitungan besar sampel menggunakan rumus pengujian hipotesis untuk dua rata-rata populasi (15), yaitu hasil perhitungan dari nilai standar deviasi kuadrat dikali $2\left(2 \delta^{2}\right)$ yang dari hasil penelitian pendahuluan didapatkan $2 \delta^{2}=2(0,905)^{2}=1,64$ kemudian dikali dengan hasil penjumlahan kuadrat dari nilai Z pada tingkat kepercayaan $95 \%$ (nilai a sebesar $5 \%$, sehingga $Z_{\alpha}=1,65$ ) dan nilai power penelitian $80 \%$ (nilai $\beta$ sebesar $20 \%$, sehingga $Z_{\beta}=0,84$ ). Hasil pengalian tersebut dibagi dengan nilai rerata perbedaan yang diharapkan dari masing-masing variabel yang dikuadratkan $\left(\mu_{1}-\mu_{2}\right)^{2}$, dari hasil penelitian pendahuluan didapatkan $\left(\mu_{1}-\mu_{2}\right)^{2}=(0,82)^{2}=$ 0,67 . Dari hasil perhitungan didapatkan $N=15,10$; dengan perhitungan drop-out sebesar $20 \%$ maka didapatkan besar sampel minimal untuk tiap kelompok sebesar 18 subjek. Dari penelitian pendahuluan sebelumnya didapatkan bahwa terapi kurkuminoid ekstrak rimpang kunyit $3 \times 30$ mg menyebabkan peningkatan hemoglobin sebesar 0,34 $\pm 0,84 \mathrm{gr} \%$, sedangkan terapi natrium diklofenak $3 \times 25 \mathrm{mg}$ menyebabkan penurunan $\mathrm{Hb}$ sebesar 0,48 \pm 0,97 gr\%.

Sampel dikumpulkan secara consecutive dari pasien OA yang terdapat di RSUP DR. Sardjito yang memenuhi kriteria inklusi. Semua subjek yang ikut dalam penelitian dilakukan washed-out selama 1 minggu, lalu dilanjutkan dengan random assignment sehingga subjek terbagi menjadi kelompok perlakuan dan kelompok kontrol. Sebelum mulai terapi, dilakukan penilaian terhadap kadar hemoglobin. Terapi diberikan selama 4 minggu, kelompok perlakuan diberikan 3×30 mg kurkuminoid ekstrak rimpang kunyit (Curcuma domestica Val.) sedangkan kelompok kontrol diberikan 3x25 mg natrium diklofenak. Penilaian hasil terapi dilakukan setelah 4 minggu terapi.

Untuk menguji perbedaan kadar hemoglobin dari kedua kelompok perlakuan dipergunakan Mann-Whitney $U$ test. Dipergunakan juga student's - $t$ test dan Wilcoxon Signed Ranks test untuk menganalisis perubahan pada masing-masing kelompok.

\section{HASIL}

Sebanyak 80 penderita osteoartritis lutut memenuhi syarat dan bersedia ikut dalam penelitian ini. Antara kelompok yang mendapat terapi kurkuminoid (kelompok kurkuminoid) dan kelompok yang mendapat terapi natrium diklofenak (kelompok diklofenak) tidak ada perbedaan bermakna dalam hal frekuensi jenis kelamin, umur, tingkat pendidikan, lamanya menderita osteoartriris, indeks massa tubuh, dan persentase penyakit penyerta $(p>0,05)$. Hal ini dapat dilihat pada Tabel 1.

Pada kelompok kurkuminoid sebanyak 5 subjek dikeluarkan dari penelitian dengan alasan: 1 subjek minum piroksikam, 1 subjek mengalami kolik ureter akibat batu saluran kencing, 1 subjek mengalami hematuria akibat tumor vesika urinaria, 1 subjek menghentikan sendiri terapi kurkuminoid atas permintaan keluarganya, dan 1 subjek 
Tabel 1. Karakteristik data dasar subjek penelitian

\begin{tabular}{|c|c|c|c|c|c|c|c|}
\hline \multirow[b]{2}{*}{ Variabel } & \multicolumn{2}{|c|}{ Jumlah (\%) } & \multicolumn{2}{|c|}{ Rerata $\pm S B$} & \multirow[b]{2}{*}{ Nilai p } & \multicolumn{2}{|c|}{ IK 95\% } \\
\hline & $\begin{array}{c}\text { Kurkuminoid } \\
(n=39)\end{array}$ & $\begin{array}{c}\text { Diklofenak } \\
(n=41)\end{array}$ & $\begin{array}{c}\text { Kurkuminoid } \\
(n=39)\end{array}$ & $\begin{array}{c}\begin{array}{c}\text { Diklofenak } \\
(n=41)\end{array} \\
\end{array}$ & & Bawah & Atas \\
\hline $\begin{array}{l}\text { Jenis kelamin (\%) } \\
\text { Pria } \\
\text { Wanita }\end{array}$ & $\begin{array}{l}11(38,5) \\
23(61,5)\end{array}$ & $\begin{array}{l}11(29,3) \\
28(70,7)\end{array}$ & - & - & 0,91 dp & - & - \\
\hline Usia (tahun) & - & - & $63,74 \pm 9,05$ & $64,56 \pm 8,73$ & $0,68^{*}$ & $-0,03$ & 0,02 \\
\hline $\begin{array}{l}\text { Pendidikan (\%) } \\
\text { Tidak tamat SD } \\
\text { SD } \\
\text { SMP } \\
\text { SMA } \\
\text { Sarjana }\end{array}$ & $\begin{array}{r}1(2,9) \\
9(26,5) \\
9(25,6) \\
8(23,5) \\
7(20,6)\end{array}$ & $\begin{array}{r}2(5,1) \\
2(5,1) \\
11(28,2) \\
13(33,2) \\
11(28,2)\end{array}$ & - & - & 0,51фрф & - & - \\
\hline Lama OA (bulan) & - & - & $42,71 \pm 33,10$ & $40,59 \pm 31,65$ & $0,74 \#$ & & \\
\hline $\begin{array}{l}\text { Lokasi OA (\%) } \\
\text { Lutut kanan } \\
\text { Lutut kiri } \\
\text { Bilateral }\end{array}$ & $\begin{array}{r}21(35,3) \\
9(26,5) \\
13(38,2)\end{array}$ & $\begin{array}{l}12(30,8) \\
14(35,9) \\
13(33,3)\end{array}$ & - & - & 1,00 фрфр & - & - \\
\hline $\begin{array}{l}\text { Aspirasi sendi (\%) } \\
\text { Kanan } \\
\text { Kiri }\end{array}$ & $\begin{array}{l}21(61,8) \\
13(38,2)\end{array}$ & $\begin{array}{l}20(51,3) \\
19(48,7)\end{array}$ & - & - & 0,36 фp & - & - \\
\hline IMT $\left(\mathrm{kg} / \mathrm{m}^{2}\right)$ & - & - & $26,76 \pm 3,40$ & $26,35 \pm 4,84$ & $0,69 \#$ & & \\
\hline Hipertensi (\%) & $17(50,0)$ & $14(35,9)$ & - & - & 0,19 dp & - & - \\
\hline DM (\%) & $7(17,9)$ & $6(14,6)$ & - & - & 0,46 dp & - & - \\
\hline Dislipidemia (\%) & $1(2,6)$ & $1(2,4)$ & - & - & 0,74 q & - & - \\
\hline Gagal jantung (\%) & $2(5,1)$ & $0(0,0)$ & - & - & 0,23 фp & - & - \\
\hline
\end{tabular}

Keterangan: * Independent t-test, \#Mann-Whitney $\mathrm{U}$ test,

ф Chi-square test / Fisher's exact test, dpq Kolmogorov-Smirnov

mengalami penyakit paru obstruktif menahun eksaserbasi akut dan menghentikan terapi kurkuminoid. Jumlah subjek pada kelompok kurkuminoid yang mengikuti penelitian ini sampai selesai adalah 34 orang, terdiri dari 10 pria dan 24 wanita.
Pada kelompok diklofenak sebanyak 2 subjek dikeluarkan dari penelitian dengan alasan: 1 subjek mengalami dispepsia pada hari ketujuh terapi yang tidak membaik dengan pemberian omeprazol $10 \mathrm{mg} 1$ tablet per hari dan 1 subjek tidak didapatkan cairan sendi pada aspirasi

Normal Q-Q Plot of HbO

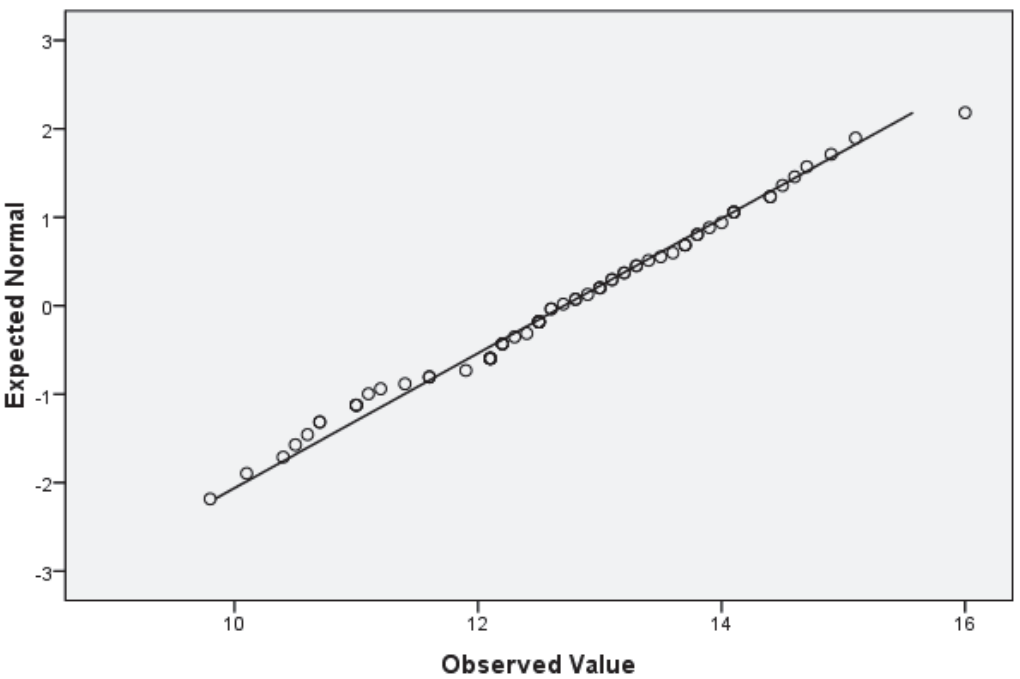

Gambar 1. Distribusi kadar hemoglobin pada kelompok kurkuminoid, nilai $p=0,200$ 


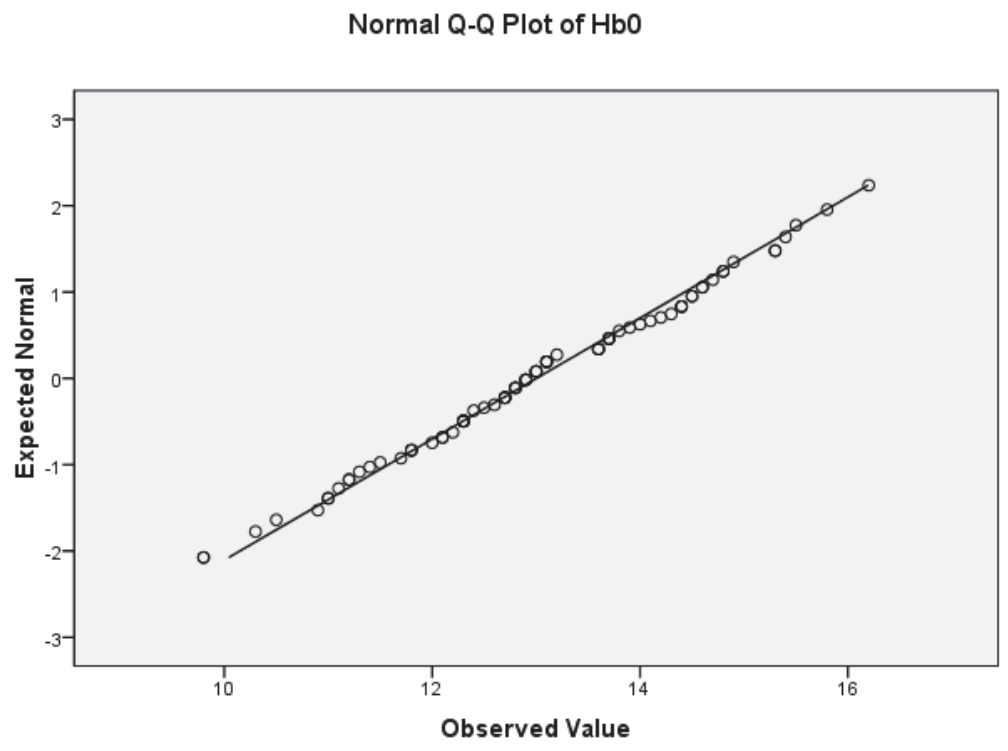

Gambar 2. Distribusi kadar hemoglobin pada kelompok diklofenak, nilai $p=0,200$

Normal Q-Q Plot of deltaHB

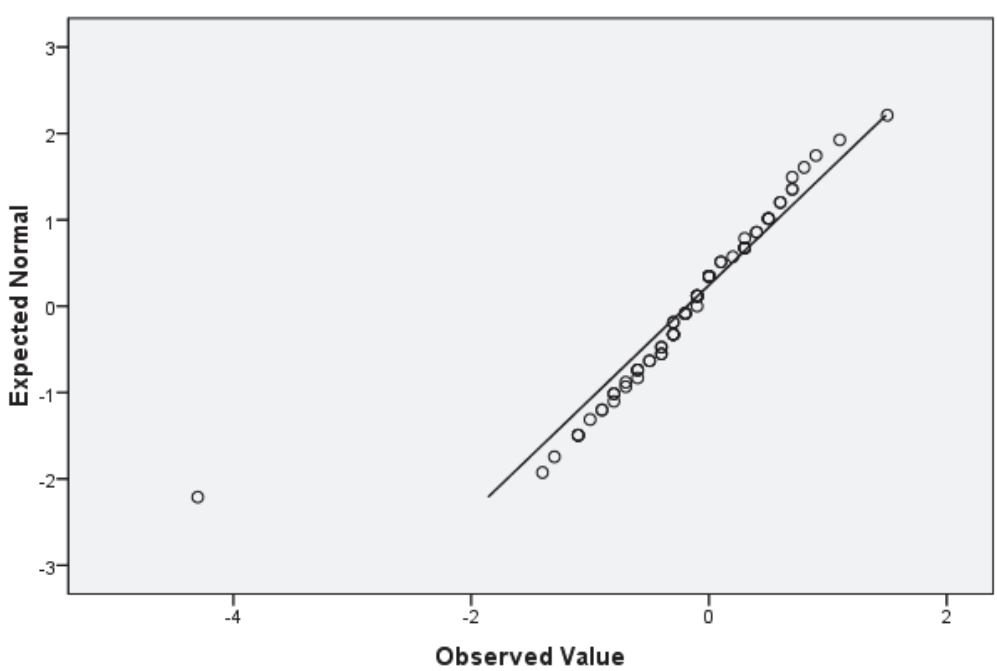

Gambar 3. Distribusi selisih kadar hemoglobin (sebelum dan setelah terapi), nilai $p=0,02$

Tabel 2. Hasil pemeriksaan kadar hemoglobin sebelum dan sesudah terapi

\begin{tabular}{|c|c|c|c|c|c|c|c|c|c|c|}
\hline \multirow{2}{*}{ Variabel } & \multicolumn{2}{|c|}{$\begin{array}{c}\text { Kurkuminoid } \\
\text { (Rerata } \pm \text { SB) }\end{array}$} & \multirow[t]{2}{*}{ Nilai $p$} & \multicolumn{2}{|c|}{ IK 95\% } & \multicolumn{2}{|c|}{$\begin{array}{c}\text { Diklofenak } \\
\text { (Rerata } \pm S B \text { ) }\end{array}$} & \multirow{2}{*}{$\begin{array}{c}\text { Nilai } \\
\mathbf{p}\end{array}$} & \multicolumn{2}{|c|}{ IK 95\% } \\
\hline & Sebelum & Sesudah & & Bawah & Atas & Sebelum & Sesudah & & Bawah & Atas \\
\hline $\begin{array}{l}\text { Hemoglobin (g/ } \\
\mathrm{dL})\end{array}$ & $\begin{array}{l}12,56 \\
\pm 1,25\end{array}$ & $\begin{array}{l}12,85 \\
\pm 1,37\end{array}$ & $0,005^{*}$ & $-0,48$ & $-0,09$ & $\begin{array}{l}13,06 \\
\pm 1,48\end{array}$ & $\begin{array}{l}12,94 \\
\pm 1,38\end{array}$ & $0,38^{*}$ & $-0,17$ & 0,38 \\
\hline
\end{tabular}

Keterangan: *Paired t-test 
Tabel 3. Perubahan kadar hemoglobin selama terapi

\begin{tabular}{|c|c|c|c|c|c|}
\hline \multirow[b]{2}{*}{ Variabel } & \multicolumn{2}{|c|}{ Rerata $\pm S B$} & \multirow[b]{2}{*}{ Nilai $p$} & \multicolumn{2}{|c|}{ IK 95\% } \\
\hline & $\begin{array}{c}\text { Kurkuminoid } \\
(n=34)\end{array}$ & $\begin{array}{c}\begin{array}{c}\text { Diklofenak } \\
(n=39)\end{array} \\
\end{array}$ & & Bawah & Atas \\
\hline Hemoglobin & $-0,28 \pm 0,56$ & $0,09 \pm 0,88$ & $0,02 \#$ & $-0,75$ & $-0,05$ \\
\hline
\end{tabular}

Keterangan: \#Mann-Whitney U test

ke dua. Jadi jumlah subjek pada kelompok diklofenak yang mengikuti penelitian ini sampai selesai adalah 39 orang, terdiri dari 11 pria dan 28 wanita.

Distribusi kadar hemoglobin sebelum dan sesudah terapi pada kedua kelompok dapat dilihat pada Gambar 1 dan 2. Pada kelompok kurkuminoid dan diklofenak didapatkan distribusi yang merata.

Pada Tabel 2 tampak peningkatan kadar hemoglobin secara bermakna akibat terapi kurkuminoid, sedangkan pada terapi natrium diklofenak kadar hemoglobin tidak berubah secara bermakna.

Pada Gambar 3 tampak bahwa distribusi selisih kadar hemoglobin sebelum dan setelah terapi tersebar tidak merata.

Pada Tabel 3 tampak peningkatan kadar hemoglobin pada kelompok kurkuminoid berbeda bermakna dengan penurunan kadarnya pada kelompok diklofenak.

\section{BAHASAN}

Kurkuminoid merupakan zat aktif yang terdapat di dalam rimpang kunyit dan temulawak, yaitu jenis kurkuma yang telah dimanfaatkan masyarakat sebagai bumbu dan komponen jamu. Khasiatnya beraneka ragam antara lain menghambat aktivitas enzim sikloksigenase dan sebagai anti-oksidan sehingga dapat dipergunakan untuk mengurangi peradangan pada penyakit reumatik. Aktivitas antiinflamasi kurkumin meliputi penghambatan sikloksigenase, penghambatan lipoksigenase dan antioksidan. Kemampuan kurkumin terbukti cukup kuat dalam menekan aktivitas enzim sikloksigenase yang dapat dibuktikan dengan penghambatan metabolisme asam arakidonat menjadi prostaglandin $\mathrm{E}_{2}\left(\mathrm{PG}-\mathrm{E}_{2}\right)$ dan prostaglandin $\mathrm{F}_{2 a}\left(\mathrm{PG}-\mathrm{F}_{2 a}\right)$ yang tergantung dosis kurkumin. Kurkumin juga mempunyai aktivitas anti tumorogenesis (11). Hasil penelitian yang dilaksanakan di Korea Selatan dan India pada tahun 2005 dan 2010 menunjukkan bahwa kurkumin mampu mencegah dan mengobati ulkus lambung $(16,17)$.

Pada Tabel 3 tampak perbedaan yang bermakna antara peningkatan kadar hemoglobin pada kelompok yang mendapat terapi kurkuminoid ekstrak rimpang kunyit dengan penurunan kadar hemoglobin pada kelompok yang mendapat terapi natrium diklofenak. Berbagai macam usaha telah dicoba untuk mengurangi terjadinya efek samping OAINS pada saluran cerna khususnya perdarahan lambung antara lain melalui cara pemberian parenteral, supositoria, topikal, dan penggunaan obat salut enterik. Melalui cara-cara tersebut, ternyata efek samping pada lambung masih saja terjadi walaupun jumlahnya berkurang. Kemajuan ilmu pengetahuan di bidang kedokteran telah menemukan 2 jenis enzim sikloksigenase yaitu COX-1 dan COX-2. Sikloksigenase-1 adalah enzim yang diperlukan tubuh untuk menjaga homeostasis fisiologis, jadi dengan dihambatnya enzim ini homeostasis fisiologis akan terganggu dan timbul efek samping obat khususnya pada saluran cerna, perdarahan, dan gangguan fungsi ginjal (18).

Natrium diklofenak tergolong preferentially selective COX inhibitor yaitu OAINS yang menekan aktivitas COX-2 sebanding dengan penekanan terhadap COX-1 meskipun pada kenyataannya sedikit lebih kuat menekan COX-2 (19). Preferentially COX inhibitor menunjukkan bahwa OAINS yang termasuk dalam golongan ini menghambat aktivitas enzim COX-1 dan COX-2 dalam porsi yang seimbang, sehingga secara umum lebih aman terhadap saluran cerna dan ginjal jika dibandingkan dengan OAINS yang selektif menghambat COX-1. Selain itu juga lebih aman terhadap sistem kardiovaskuler jika dibandingkan dengan OAINS yang selektif menghambat COX-2 (3). Albumin kolon yang merupakan petunjuk terjadinya perdarahan saluran cerna sudah diperiksa juga dalam penelitian ini. Berdasarkan penelitian ini ditemukan bahwa frekuensi kejadian albumin kolon yang positif pada kelompok yang mendapat terapi kurkuminoid ekstrak rimpang kunyit tidak mengalami perubahan yang bermakna selama terapi $(p=0,69)$, namun pada kelompok yang mendapat terapi natrium diklofenak terjadi peningkatan yang bermakna $(p=0,03)$.

Gangguan saluran cerna kadang terjadi pada terapi dengan natrium diklofenak. Pada penelitian ini dilakukan juga penilaian kejadian rasa mual akibat terapi pada kedua kelompok tersebut. Pada kelompok yang mendapat terapi natrium diklofenak sebanyak $4,9 \%$ pasien mengalami rasa mual, sedangkan pada kelompok terapi kurkuminoid ekstrak rimpang kunyit tidak ada pasien yang merasakan mual, dengan nilai number needed to harm (NNH) sebesar 21. Hal ini berarti jika sebanyak 21 subjek diberikan terapi natrium diklofenak atau kurkuminoid ekstrak rimpang kunyit maka akan ada satu subjek yang mual pada kelompok diklofenak, sementara tidak ada subjek yang mual pada kelompok kurkuminoid. Rasa mual akan mengganggu 
asupan gizi pasien yang dapat menyebabkan penurunan kadar hemoglobin.

Diare adalah salah satu gangguan saluran cerna yang bisa terjadi pada terapi dengan natrium diklofenak. Pada penelitian ini juga sudah diteliti kejadian diare akibat terapi kurkuminoid ekstrak rimpang kunyit dibandingkan dengan natrium diklofenak. Pada kelompok yang mendapat terapi natrium diklofenak sebanyak $2,4 \%$ pasien mengalami diare, sedangkan pada kelompok terapi kurkuminoid ekstrak rimpang kunyit tidak ada pasien yang mengalami diare, dengan nilai number needed to harm (NNH) sebesar 42. Hal ini berarti jika sebanyak 42 subjek diberikan terapi natrium diklofenak atau kurkuminoid ekstrak rimpang kunyit maka akan ada satu subjek yang mengeluh diare pada kelompok diklofenak, sementara tidak ada subjek yang diare pada kelompok kurkuminoid. Diare bisa mengakibatkan gangguan absorpsi gizi sehingga bisa menyebabkan penurunan kadar hemoglobin.

Hasil penelitian ini yaitu adanya perbedaan yang bermakna antara peningkatan kadar hemoglobin pada kelompok yang mendapat terapi kurkuminoid ekstrak rimpang kunyit dengan penurunan kadar hemoglobin pada kelompok yang mendapat terapi natrium diklofenak, didukung oleh hasil-hasil penelitian sebelumnya (20). Kadar hemoglobin adalah salah satu faktor penting yang menentukan kesehatan populasi lanjut usia. Penurunan kadar hemoglobin akan menurunkan fungsi kognitif serta meningkatkan morbiditas dan mortalitas populasi lanjut usia (14). Osteoartritis merupakan penyakit degeneratif yang cenderung menyerang populasi lanjut usia. Pada penelitian ini didapatkan rerata umur subjek pada kelompok terapi

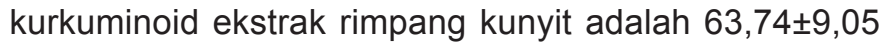
tahun dan pada kelompok terapi natrium diklofenak $64,56 \pm 8,73$ tahun. Dengan demikian perlu diwaspadai terjadinya penurunan kadar hemoglobin akibat terapi yang diberikan khususnya terapi dengan obat anti-inflamasi nonsteroid. Bukti-bukti penelitian menunjukkan bahwa OAINS mempunyai efek samping yang serius terutama jika dipergunakan dalam jangka lama, lebih-lebih pada pasien usia lanjut. Efek samping OAINS dapat berupa perdarahan saluran cerna, gangguan fungsi hati, ginjal, sumsum tulang, serangan jantung, dan stroke (21). Berbagai efek samping akibat terapi OAINS diduga mempengaruhi perubahan kadar hemoglobin pasien.

\section{KESIMPULAN}

Pada penelitian ini, dapat ditarik kesimpulan bahwa terdapat perbedaan bermakna antara peningkatan kadar hemoglobin pada kelompok yang mendapat terapi kurkuminoid ekstrak rimpang kunyit dengan penurunan kadar hemoglobin pada kelompok yang mendapat terapi natrium diklofenak pada penderita osteoartritis. Adanya peningkatan kadar $\mathrm{Hb}$ ini dapat menjadi salah satu keuntungan dari terapi kurkuminoid dibandingkan natrium diklofenak terkait efek samping anemia akibat gastritis erosiva atau ulkus peptikum yang sering terjadi pada terapi dengan obat anti-inflamasi non-steroid seperti natrium diklofenak.

\section{SARAN}

Berhubung pada terapi dengan kurkuminoid ekstrak rimpang kunyit terjadi peningkatan kadar hemoglobin yang bermakna dibandingkan dengan terapi natrium diklofenak, maka disarankan penggunaan kurkuminoid ekstrak rimpang kunyit pada terapi osteoartritis.

\section{Ucapan terima kasih}

Penelitian ini terlaksana atas bantuan serta dukungan berbagai pihak. Peneliti mengucapkan terima kasih kepada Direktur RSUP Dr. Sardjito Yogyakarta beserta seluruh jajarannya, dan semua pihak yang telah membantu terlaksananya penelitian ini.

\section{RUJUKAN}

1. Psaty BM, Furberg CD. COX-2 inhibitors - lessons in drug safety. N Engl J Med 2005; 352:1133-5.

2. Timmerman $\mathrm{H}$. New perspective for anti-inflammatory drugs in Pramono, S (ed). Curcumin pharmacochemistry. Yogyakarta: Aditya Media; 1995.

3. Alvarez-Soria MA, Largo $\mathrm{R}$, Sanchez-Pernaute $\mathrm{O}$, Calvo E, Egido J, Herrero-Beaumont G, Santillana $\underline{J}$, Hernandez M. Long term NSAID treatment inhibits COX-2 synthesis in the knee synovial membrane of patients with osteoarthritis: differential proinflammatory cytokine profile between celecoxib and aceclofenac. Ann Rheum Dis 2006; 65(8):998-1005.

4. Kalim H, Hidayat M, Loekito RM, Hanafi M, Tjahjono CT, Iskandar A, Kusworini H. Masalah penyakit reumatik di masyarakat Malang. Dalam: Kalim $\mathrm{H}$, Kusworini H, Hidayat M, (eds). Naskah Seminar dan Workshop Osteoartritis. Malang: Fakultas Kedokteran Universitas Brawijaya; 1996. 5-10

5. Sampurno. Informasi temu lawak Indonesia. Jakarta: Badan Pengawas Obat dan Makanan Republik Indonesia; 2004.

6. Joe B, Vijaykumar M, Lokesh BR. Biological properties of curcumin, cellular and molecular mechanisms of action. Crit Rev Food Sci Nutr 2004; 44(2):97-111.

7. Santoso B, Warih B, Pramono S. Uji klinik pendahuluan ekstrak perasan kunyit sebagai obat gastritis (laporan penelitian). Yogyakarta: Pusat Penelitian Obat Tradisional Universitas Gadjah Mada; 1991.

8. Pramono S. Standarisasi kadar kurkumin dalam ekstrak kunyit dengan aktivitas anti ulkus lambung. 
Dalam: Wiryowidagdo S, Darise M, Sudirman I, Wahyudin E, Wunas J, (eds). Simposium Penelitian Tumbuhan Obat VII. Ujung Pandang; 1993. 86-90.

9. Santosa MH, Dyatmiko W, Soemarto R, Adi P, Zaini NC. Efficacy of standardized temu lawak extract capsule on chronic hepatitis patients (abstract). International Symposium on Curcumin Pharmacochemistry (ISCP). Yogyakarta; 1995.

10. Hadi S. Khasiat fitofarmaka pada hepatitis. Simposium Hepatitis. Yogyakarta; 1996.

11. Huang MT, Ma W, Lou YR, Lu YP, Chang R, Newmark $\mathrm{H}$, Conney $\mathrm{AH}$. Inhibitory effect of curcumin on tumorigenesis in mice. In Pramono S, (ed). Curcumin pharmacochemistry. Yogyakarta: Aditya Media; 1995. 47-63.

12. Kertia N, Danang, Broto $R$, Rahardjo $P$, Asdie $A H$. Increase quality of service for patients with osteoarthritis by using the combination of curcuminoid and curcumin's atsiri oil. In Abstract of $9^{\text {th }}$ Asia Pacific League of Associations for Rheumatology Congress. Beijing; 2000.

13. Kertia N, Neneng R. Perbandingan efek samping pada hati dan saluran cerna antara ekstrak kunyit dengan natrium diklofenak pada penderita osteoartritis. Yogyakarta: Laporan Penelitian, Fakultas Kedokteran Universitas Gadjah Mada; 2004.

14. Denny SD, Kuchibhatla MN, Cohen HJ. Impact of anemia on mortality, cognition and function in communitydwelling elderly. Am J Med 2006; 119:327-34.
15. Lemeshow S, Hosmer DW, Klar J, Lwanga SK. Adequacy of sample size in health studies. (terjemahan) Pramono D. Yogyakarta: Gadjah Mada University Press; 1997.

16. Kim DC, Kim SH, Choi BH, Baek N, Kim D, Kim MJ. Curcuma longa extract protects against gastric ulcers by blocking $\mathrm{H} 2$ histamine receptors. Biol Pharm Bull 2005; 28(12): 2220-4.

17. Kundu P, De R, Pal I, Mukhopadhyay AK, Saha DR, Swarnakar S. Curcumin alleviates matrix metalloproteinase-3 and -9 activities during eradication of helicobacter pylori infection in cultured cells and mice. Plos One 2010; 6(1): e16306. doi:10.1371.

18. Tseng CC, Wolfe MM. Nonsteroidal anti-inflamatory drugs. Med Clin N Am 2000; 84:1329-44.

19. Kertia N. Peran preferentially selective COX inhibitor dalam pengobatan nyeri reumatik. Dalam Simposium Osteoporosis, Nyeri Reumatik, dan Stroke. Yogyakarta: Fakultas Kedokteran Universitas Gadjah Mada; 2004. 3-14

20. Aggarwal BA, Bhatt ID, Ichikawa H, Ahn KS, Sethi G, Sandur SK. Curcumin-biological and medicinal properties [serial online] 2006 [cited 2011 Feb 24]. Available from:URL: http://www.indsaff.com/10 Curcumin biological. pdf.

21. Daniel L, Simmons, Regina M, Botting, Timothy HLA. Cycloxygenase isozyme: the biology of prostaglandin synthesis and inhibitiom. Pharmacol Rev 2004; 56(3):387-437. 